Jurnal ABDIMAS INDEPENDEN

Vol. 1, No. 2, November 2020

\title{
PENYULUHAN BIDANG PRODUKSI UMKM INDUSTRI TEMPE DI LINGKUNGAN ABIAN KELURAHAN PEJERUK AMPENAN
}

\author{
M. Ilhamudin, Ahyar, Weni Retnowati, Santi Nururly, dan Hilmiati \\ Jurusan Manajemen - Universitas Mataram \\ ilham.alfian226@gmail.com
}

\begin{abstract}
ABSTRAK
Peran Usaha Mikro, kecil, dan Menengah (UMKM) dalam perekonomian nasional sangatlah besar, demikian pula halnya untuk di kota Mataram Provinsi Nusa Tenggara Barat (NTB). Di Kota Mataram sebagian besar UMKM dalam bentuk Industri kecil dan kerajinan dengan berbagai jenis produk yang dihasilkan. Tujuan dari kegiatan pengabdian pada masyarakat ini adalah: (1) meningkatkan pengetahuan kepada pelaku usaha dan karyawan mengenai manajemen produksi, (2) meningkatkan pengetahuan dan keterampilan memproyeksi permintaan hasil produksi, dan (3) memberikan penyuluhan lokasi usaha, layout, manajemen persediaan dan kualitas. Kegiatan ini dilakukan pada sentra industri tempe di lingkungan Abian kelurahan Pejeruk Ampenan kota Mataram. Kegiatan dilakukan pada bulan juli hingga September 2019 dengan metode penyuluhan dan diskusi. Hasil kegiatan pelaku usaha dan karyawan dapat meningkatkan pengetahuan dan ketrampilan untuk mengelola usahanya dalam konteks manajemen produksi; yaitu tentang proyeksi permintaan hasil produksi,lokasi usaha,layout, manajemen persediaan, dan kualitas produk.
\end{abstract}

Kata Kunci: penyuluhan, manajemen produksi, industri tempe

\section{PENDAHULUAN}

Peran Usaha Mikro, Kecil, dan Menengah (UMKM) dalam perekonomian nasional sangatlah besar. Hal itu sudah tidak dapat diragukan lagi. Kementerian Koperasi dan Usaha Kecil Menengah pada tahun 2008 menyebutkan bahwa jumlah usaha UMKM di Indonesia mencapai sekitar 56,5 juta, dan 99,8 persennya adalah dari sektor UMKM. Oleh karena itu, UMKM di Indonesia berkontribusi sebesar 97 persen dalam penyerapan tenaga kerja.

Di kota Mataram, sebagian besar UMKM dalam bentuk industri kecil dan kerajinan dengan berbagai jenis produk yang dihasilkan. Usaha-usaha tersebut lebih bersifat home industry, yakni kegiatan usaha berbasis di rumah, dilakukan oleh keluarga yang bertempat tinggal di situ dan mengajak beberapa orang di sekitarnya sebagai tenaga kerja. Salah satu home industry di Kota Mataram adalah industri tempe di Lingkungan Pejeruk Abian Kelurahan Pejeruk Ampenan. 
Permasalahan yang dihadapi oleh pengusaha tempe di lingkungan Abian Pejeruk Ampenan sama dengan UMKM pada umumnya, yaitu berkaitan dengan kemampuan pengolahan usaha yang kurang profesional, dicirikan dengan penggunaan keluarga sebagai pengelola, kurangnya pengetahuan yang berhubungan dengan fungsi bisnis seperti fungsi produksi, organisasi, dan pengembangan bisnis ke depan. Dalam konteks manajemen produksi permasalahan yang selalu ditemui berkaitan dengan ketidakmampuan manajemen mengukur permintaan masa datang, perencanaan produksi belum sesuai dengan pemilikan sumber daya internal. Masalah lain adalah tata letak fasilitas yang kumuh dan mengganggu proses produksi, kurang terencananya persediaan bahan dan barang jadi padahal produk makanan cepat rusak, dan masalah kualitas produk serta produktivitas (Aziz, 2017).

Industri tempe di Pejeruk Abian masih dilakukan secara tradisional. Meskipun demikian produk tempe yang dihasilkan memiliki cita rasa yang khas, dengan kualitas dan kadar gizi yang tinggi. Proses pembuatan tempe di sentra industri ini sama dengan pembuatan tempe tradisional pada umumnya.

Pelaku indsutri sudah memahami cara membuat produk tempe ini karena diwariskan secara turun-temurun. Namun seperti halnya kebanyakan usaha kecil, UMKM penghasil tempe di kelurahan Pejeruk Abian juga mengalami kendala dalam hal manajemen produksi. Pengabdian ini ditujukan bagi UMKM penghasil tempe agar pengusaha bersangkutan dapat menegmbangkan kemampuannya dalam hal memanaj aktivitas produksinya, seperti meramal permintaan, merencanakan produksi, merencanakan tata letak fasilitas, pengendalian bahan dan kualitas, dan manajemen produktivitas.

Berdasarkan hasil identifikasi masalah yang telah dilakukan, ada beberapa permasalahan yang dihadapi pengusaha tempe di Pejeruk Abian, yaitu:

1. Persaingan yang cukup ketat karena banyaknya pesaing

2. Para pengusaha tempe di Pejeruk Abian belum cukup memiliki pengetahuan yang memadai dalam manajemen produksi. 


\section{Jurnal ABDIMAS INDEPENDEN}

Vol. 1, No. 2, November 2020

\section{METODE KEGIATAN}

Metode yang digunakan dalam kegiatan pengabdian pada masyarakat ini terdiri:

1. Tahap Pendahuluan

Tim pengabdian masyarakat membuat perencanaan kegiatan dengan melakukan survey ke lokasi kegiatan terlebih dahulu. Dari hasil survey ke lokasi dengan menemui pengelola usaha tempe di Pejeruk Abian

2. Tahap Penyuluhan

Tahap Penyuluhan meliputi kegiatan penyampaian materi dalam bentuk penyuluhan, yang berisi tentang pentingnya manajemen produksi, dengan materi peramalan, perencanaan produksi, layout, tehnik pengendalian persediaan dan kualitas, serta manajemen produktivitas. Materi lain adalah berhubungan dengan manajemen produktivitas yaitu tentang bagaimana membangun hubungan kerja yang harmonis dengan karyawan, membuat standar operasional prosedur (SOP) sehingga proses produksi berlangsung efektif dan efisien. Selain itu, penyampaian materi juga akan dilengkapi dengan diskusi.

Sebagai narasumber dalam kegiatan pengabdian adalah Tim Pengabdian Kepada Masyarakat (PPM) Fakultas Ekonomi dan Bisnis (FEB) Universitas Mataram (Unram). Untuk menunjang kelancaran kegiatan ini, maka akan dikoordinasikan dengan lembaga terkait, yaitu: Lembaga Penelitian dan Pengabdian pada Masyarakat (LPPM) Universitas Mataram, Dekan Fakultas Ekonomi dan Bisnis (FEB) Universitas Mataram, dan pengelola usaha tempe di Pejeruk Abian.

3. Tahap Evaluasi

Evaluasi dari keberhasilan penyuluhan ini akan dilihat dari kehadiran peserta dan keaktifan peserta dalam memberi respon terhadap materi yang diberikan selama penyuluhan berlangsung. Kegiatan evaluasi di laksanakan di akhir bulan September 2019. 


\section{HASIL DAN PEMBAHASAN}

1. Tahap Pendahuluan

Kegiatan pengabdian ini adalah merupakan kegiatan tindak lanjut dari kegiatan pengabdian tahun lalu. Perbedaannya adalah pada konteks materi, kegiatan sekarang lebih memusatkan pada aspek produksi yang meliputi tehnik forecasting, perencanaan produksi, proses dan layout, manajemen persediaan dan produktivitas, sedangkan kegiatan sebelumnya pada aspek pemasaran dan keuangan.

Kegiatan pendahuluan dilakukan dalam bentuk survey untuk melihat sejauh mana pelaku industri memahami dan mengimplementasi aspek produksi pada usahanya. Kegiatan dilakksanakan pada awal bulan Juli 2019. Dari survey diketahui bahwa pelaku industri ada memiliki pengalaman untuk memprediksi permintaan hasil produksi, menentukan jumlah produksi, bagaimana mengatur layout dan proses produksi, mengendalikan bahan baku, barang dalam proses dan lain sebagainya. Hanya saja permintaan saat ini semakin fluktuatif dan lebih sulit diramal, persaingan produk sejenis semakin ketat, maka pengetahuan aspek produksi semakin diperlukan. Pemahaman yang lebih baik pada aspek ini akan meminimalisir kerugian yang mungkin timbul dari kesalahan perencanaan produksi dan pengendaliannya.

Dari hasil survey pendahuluan, kemudian dibuat suatu rancangan materi yang relevan, sederhana dan mudah dimengerti. Materi pokok berkisar pada konsep peramalan penjualan, menentukan jumlah produksi optimal, desain proses dan layout yang efisien, manajemen persediaan, dan konsep produktivitas. Keseluruhan materi ini saling berhubungan sehingga menjadi satu kesatuan pengetahuan yang dibutuhkan pelaku industri agar kegiatan proses produksi bisa berlangsung lebih efektif dan efisien.

2. Tahap Penyuluhan

Sebelum dilakukan penyuluhan, berbagai hal menyangkut teknis pelaksanaan dipersiapkan seperti penentuan jumlah peserta, tempat, dan 


\section{Jurnal ABDIMAS INDEPENDEN}

Vol. 1, No. 2, November 2020

waktu penyuluhan. Kegiatan penyuluhan dilaksanakan pada bulan Juli 2019 yang diikuti oleh 17 orang peserta dari unsur pelaku usaha dan pekerja UMKM tempe di Pejeruk Abian Ampenan.

Adapun materi penyuluhan adalah sebagai berikut:
a. Pentingnya manajemen produksi
b. Peramalan dan perencanaan produksi
c. Proses produksi dan layout
d. Pengendalian persediaan
e. Manajemen produktivitas.

Setelah penyampaian materi melalui ceramah dilakukan tanya jawab tentang hal-hal yang berhubungan dengan materi yang disampaikan maupun pengalaman usaha peserta. Kegiatan penyuluhan tersebut sangat partisipatif dan kondusif kalau melihat respons yang antusias dari peserta yang memberikan pertanyaan atau berbagi pengalaman di antara mereka, dan memberi solusi atas persoalan yang dihadapi.
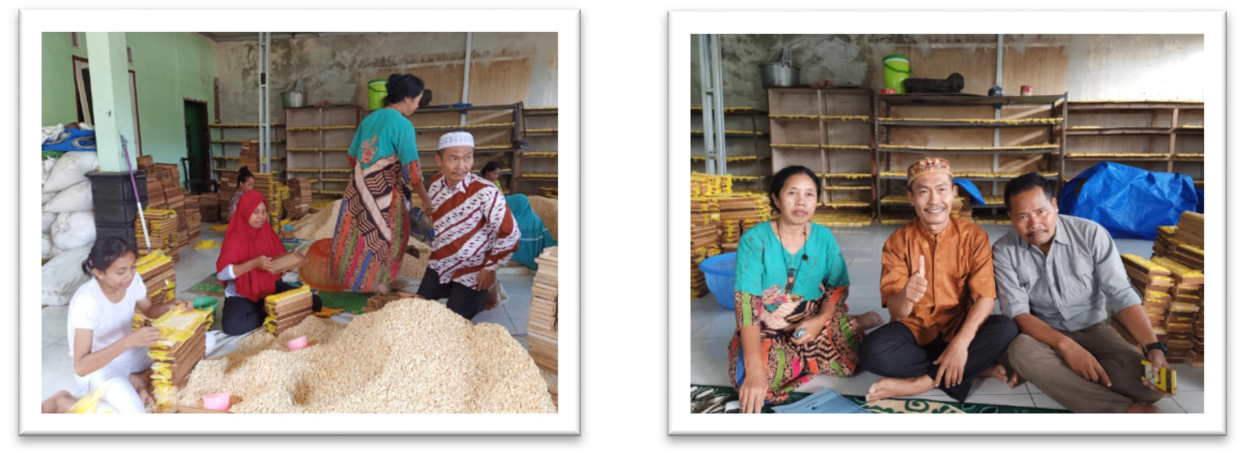

Gambar 1. Kegiatan Pengabdian Pada Masyarakat pada pelaku usaha tempe

\section{Tahap evaluasi}

Evaluasi kegiatan menunjukkan kegiatan pengabdian pada masyarakat ini berhasil, pengetahuan peserta penyuluhan meningkat yang ditunjukkan dengan kegiatan berlangsung partisipatif, persoalan lapangan banyak sekali berhubungan dengan pengetahuan ini. Peserta banyak menyampaikan 
pertanyaan, berbagi pengalaman, dan mengajukan solusi sendiri atas masalah produksi yang dihadapi. Pengetahuan ini membantu mereka membangun keunggulan bersaing yang bersumber dari aktivitas produksi yang lebih efektif, efisien, dan lebih berkualitas.

\section{KESIMPULAN DAN SARAN}

\section{Kesimpulan}

Pengetahuan pelaku usaha dan karyawan industri tempe meningkat pada aspek manajemen produksi, pengetahuan dan ketrampilan tentang bagaimana melakukan peramalan permintaan hasil produksi, dan merencanakan jumlah produksi dan kualitas, lokasi usaha, layout, mengendalikan persediaan dan membangun produktivitas.

\section{Saran}

Kegiatan pengabdian berikutnya disarankan untuk menekankan pada penyampaian pengetahuan yang lebih mendalam pada aspek-aspek manajemen produksi. Konsep manajemen produksi sangat luas, tidak bisa dipahami dengan sekali kegiatan namun berkesinambungan. Pemahaman yang lebih detail membantu pelaku industri tempe Pejeruk Abian untuk dapat mengantisipasi ketatnya persaingan dalam industri. Mereka membutuhkan daya saing yang dibangun pada lapisan kegiatan produksi/operasi.

\section{UCAPAN TERIMA KASIH}

Terima kasih tim pengabdian mengucapkan kepada Dekan Fakultas Ekonomi dan Bisnis Universitas Mataram, Ketua Lembaga Penelitian dan Pengabdian Pada Masyarakat Universitas Mataram, serta para pelaku usaha di Industri Tempe Pejeruk Abian sehingga kegiatan ini dapat berjalan dengan lancar. Kegiatan pengabdian pada masyarakat ini sehingga dapat berjalan dengan 
Jurnal ABDIMAS INDEPENDEN

Vol. 1, No. 2, November 2020

lancer bersumber dari Dana DIPA BLU Universitas Mataram Tahun Anggaran 2019.

\section{DAFTAR PUSTAKA}

Aziz N. 2007. Penerapan Sisitem Informasi Pemasaran pada Usaha Kecil Menengah (UKM) di Kota Malang. Universitas Muhammadiyah. Malang.

Kementerian Koperasi dan Usaha Kecil Menengah, 2008. UU No. 20 Tahun 2008 Tentang Usaha Mikro Kecil dan Menengah. www.bi.go.id 